\title{
Expert Review on Games for Basic Graphic Course Via M- Learning
}

\section{Irwan Mahazir Ismail $^{1 *}$, Masturah Zainal ${ }^{2}$, Harliana Halim ${ }^{3}$}

${ }^{1}$ Centre for Instructional Technology and Multimedia

Universiti Sains Malaysia, Penang, MALAYSIA

${ }^{2}$ Faculty of Technical and Vocational Education

Universiti Tun Hussein Onn Malaysia, Parit Raja, Johor, MALAYSIA

${ }^{3}$ Centre for General Studies and Co-curricular

Universiti Tun Hussein Onn Malaysia, Parit Raja, Johor, MALAYSIA

*Corresponding Author

DOI: https://doi.org/10.30880/jts.2019.11.02.004

Received 19 December 2019; Accepted 25 December 2019; Available online 31 December 2019

\begin{abstract}
The application of mobile learning or m-learning had been applied previously to the world including in the Western and Asian countries. In Malaysia, especially in the Faculty of Technical and Vocational Education (FPTV), the application of Information and Communication Technology (ICT) is an important aspect of teaching and learning (PnP). Therefore, a game-based Android m-learning application for the Basic graphics course has been developed. Accordingly, the gameplay and functionality of the game-based Android m-learning game for the Basic graphics course has been conducted. A set of questionnaire forms was used as an instrument was given to three experts in their respective fields to evaluate and give a view to the developed m-learning application. The results of this study can be used as an improvement to the application developed to ensure it is in good condition.
\end{abstract}

Keywords: Evaluation, Teaching and Learning, M-learning, Game Methods

\section{Introduction}

M-learning is one of the important facility and needs for a student in order to gain knowledge and skills in today's learning system. Additionally, M-learning gives students the freedom to learn and acquire extensive information resources for their own use. In the Technique and Vocational Education (TVE) sector, especially at the University of Tun Hussein Onn Malaysia (UTHM), M-learning are able to produce competitive learners who are able to master the generic skills that must be present in each student as well as to enhance their motivation for learning (Abd Rahman, R. and Mohd Hashim, MH, 2011). According to Anuar R. and Wan Zakaria W.Z., (2015) M-learning is not a difficult thing to implement in Malaysia as every student has the ability to have mobile devices, especially for students in the higher level of education.

The game method is one of the methods that involves the transferring process of knowledge, experiences and ideas to students in a fun atmosphere (Mohd Ismail, Kamarul Azmi, Azhar, Rujalah \& Saodah, 2012). Therefore, the application of game modes in teaching and learning session has been infused into a m-learning applications that were developed earlier. Additionally, games are not only just limited to children but they have no limit again age. At the educational center especially for students of higher learning institutions (IPT), most of the students have the experience of playing a digital games that were downloaded into their smartphones (Whitton, 2010). 
Moreover, the implementation of multimedia elements such as text, images, audio, video and animation in the design and development of mobile applications can attract and motivate the students to learn continuously. Furthermore, the findings from a research done shows that the teaching method that implements interactive multimedia has a positive impact on the achievement of students (Ismail Basiron, 2012). Therefore, the learning method needs to be in line with the interests, attitudes and the needs of today's generation that emphasizes more on the use of Information and Communication Technology (ICT) especially for mobile devices. In accordance to that, the game-based Android app for the Basic Graphic course has been developed using the ADDIE model as the design model for teaching and learning while at the same time, as suggested by Koole (2009), the FRAME model was used as a guide in m-learning development.

\section{Problem Statement}

User Interface Design or User Experience (UI / UX) is not just merely a graphic design but it is the core skills that is required for the development and development of effective mobile app as stated by Udell (2014). The findings show that the teaching methods that implements the interactive multimedia have given out a positive impact on the student's achievement (Ismail Basiron, 2012). It is therefore important to ensure that every detail of the interface design, interaction and content for the application that will be developed for m-learning is appropriate and suitable.

The implementation of several multimedia elements such as text, images, audio, video and animation in the design and development of mobile applications can attract and motivate students to learn continuously. Additionally, the capabilities of smartphones that comes with the latest technology are able to display and produce effective multimedia elements as well as providing a quick feedback thus creating an impact on the student's learning and makes teacher's teaching duty easier (Mohamad Siri Muslimin et al., 2017). However, the choice of appropriate multimedia elements should be considered according to the background of the respondents in terms of demographic and learning styles. It is also stressed by Koole (2009) that an individual or a learner's learning aspects involves cognitive abilities, prior knowledge, emotion and motivation.

The process of teaching and learning $(\mathrm{P} \& \mathrm{P})$ consists of methods, techniques, strategies and materials to ensure that the learning objectives are achieved. P \& P process does not only happen in a lecture hall but it is a continuous process. In the Android-based and game-based mobile learning (m-learning) learning applications for Basic Graphics course, the researcher applied the constructivism learning theories as the basis of the learning process that will takes place through the use of mobile applications. According to Haizum Hanim Ab. Halim, \& Lai (2011), the word constructivism derives from the English word "Constructivism" which has the meaning of building philosophy. In this case, the developed application are aimed to generate an existing knowledge for the students and the knowledge is then will be applied in future learning process such as the one provided in the game.

\section{Research Objectives and Research Questions}

The objectives of this study is for the experts to assess the functionality of an Android-based and game based mobile learning applications (m-learning) that has been developed for the students from Basic Graphic course. The findings of the study can be used to improve the application of m-learning to ensure that every requirement in a teaching and learning process is fulfilled.

This research will answer these questions:

i. Does the m-learning's game-based and Android-based application functions properly?

ii. What are the experts view on the developed m-learning's game-based and Android-based application?

\section{Methodology}

A set of questionnaires was developed using Google Forms to be answered by the experts. The selected respondents are a personnel who are experts and skilled in the field of instructional design. This is so that a more genuine feedback regarding to the m-learning applications that has been developed by the researcher can be obtained. This questionnaire consists of 3 parts. Part A is the respondent's demographic information that contains 4 questions and Part B and Part C is related to the functionality and usability of the Android and game-based m-learning application for the Basic Graphic course.

In the questionnaire provided there were two items that were left opened for the respondents to provide suggestions or views on the developed Android apps that uses the game method for the Basic Graphic course learning topics. The data obtained were analyzed using descriptive statistics using frequency and percentage. The questionnaire was adapted and modified from Aliff Nawi, Mohd Isa Hamzah and Surina Akmal Abd Sattai (2014). 


\section{Research Findings and Discussion}

Part A of the questionnaire in this research was related to the respondents' demographic information. The respondent of this research comprises of three experts in their respective fields who were lecturers at public and private educational institutions. Two of the experts from the Graphic Design field have a Bachelor and Master as their academic qualification respectively while another expert have a Doctor of Philosophy in Educational Technology as an academic qualification. These experts have around 5 to 10 years of experience in their field.

Table 1 : The Functionality and Usability of Basic Graphic M-Learning Application

\begin{tabular}{cc|c|c|c}
\hline No & \multicolumn{1}{c|}{ Statement } & \multicolumn{2}{c}{ Frequency } & \multicolumn{2}{c}{ Percentage } \\
\hline $\mathbf{1 .}$ & Is this application easy to use? & Yes & 3 & 100 \\
\hline $\mathbf{2}$ & Can this app be used without the help of others? & Yes & 3 & 100 \\
\hline $\mathbf{3}$ & Is the User Manual easy to use? & No & 3 & 100 \\
\hline $\mathbf{4}$ & Does this app display information quickly? & Yes & 3 & 100 \\
\hline $\mathbf{5}$ & Does this app require a short time to master? & Yes & 3 & 100 \\
\hline $\mathbf{6}$ & Can the users change any subtopics at any given & Yes & 3 & 100 \\
\hline $\mathbf{7}$ & Can the user logs out from the application anytime? & Yes & 3 & 100 \\
\hline $\mathbf{8}$ & Does the navigation button work properly? & No & 3 & 100 \\
\hline
\end{tabular}

Table 1 shows the respondents' distribution of functionality and usability of the app from three experts. The findings shows that the Basic Graphic Learning course mobile learning application that has been developed is easy to be used and it can be used without the help of others. In addition to that, the expert respondents agrees with the notion that the Basic Graphic m-learning application displays information quickly with only short time needed to master the application, while at the same time the user can change any subtopics and exit the app at any time. However, the basic Graphic application did not have a user manual for the application usage. Additionally, the experts' reviews find that the application navigation buttons did not work properly.

The researcher also included two open questions for the participated experts to evaluate the developed Android applications that uses the game method for the Basic Graphic topics in Part C. Table 2 is the suggestions and opinions given by experts related to the multimedia elements (text, graphics, animation, video and audio) that were applied in the Basic Graphic m-learning application. Multimedia elements are an important aspect of m-learning applications that has been developed because a proper selection of text, graphics, animation, video and audio needs to be considered in developing the app.

Table 2: Multimedia Elements (Text, Graphics, Animation, Video and Audio) in the Basic Graphic Application

\begin{tabular}{cl}
\hline Experts & \multicolumn{1}{c}{ Statement } \\
\hline Expert 1 & $\begin{array}{l}\text { "Overall it satisfy the needs for each stated elements since it includes all the } \\
\text { elements." }\end{array}$ \\
\hline Expert 2 & $\begin{array}{l}\text { "The multimedia elemen used is suitable for the intended user level. The design } \\
\text { for the button on the video maybe can be upgraded so that it is more interesting." }\end{array}$ \\
\hline Expert 3 & "Good. But there are several non-functioning button." \\
\hline
\end{tabular}

Other than that, the experts also give their opinion and suggestion to improve and upgrade the m-learning's gamebased and Android-based application that has been. Below are the opinion and suggestion from the experts.

Table 3 : Opinion and Suggestion for Improvement

\begin{tabular}{cl}
\hline Experts & \multicolumn{1}{c}{ Statement } \\
\hline Expert 1 & "Make sure the navigation button functions properly." \\
\hline Expert 2 & $\begin{array}{l}\text { "Overall it is good. There are several navigation buttons that needs to be } \\
\text { improved. More games should be added." }\end{array}$ \\
\hline Expert 3 & $\begin{array}{l}\text { "Include more games. The colour of the buton on the video is too over the top and } \\
\text { the text is not suitable. Overall it is good." }\end{array}$ \\
\hline
\end{tabular}


The expert's opinion and suggestion on how to improve m-learning's game-based and Android-based application for the basic graphic course are for the researcher to make sure the navigation button functions properly according to its link and its correct control. Other than that, the researcher should also add more games. The experts finds that the colour of the link button on the video is too flashy with the type of text is not that suitable. This is because the colour usage is too contrast with the bright colour of the background.

\section{Conclusion}

It is hoped that the m-learning application that has been developed will help students to increase their knowledge beyond the classroom as well as encouraging a student-based learning. There are also helping aids prepared that is expected to provide a fun learning environment with the implementation of games method in this application. Every opinion and suggestion that were given by the experts will be seriously taken into consideration for the improvement of the developed application before it can be applied to the teaching and learning proses and also for the users to use it.

\section{Acknowledgment}

This article was supported by the Department of Social Sciences, Centre for General Studies and Co-Curricular, Universiti Tun Hussein Onn Malaysia.

\section{References}

Abd Rahman, Rossyahida \& Mohd Hashim, Mohamad Hisyam (2011). M-pembelajaran Dalam Pendidikan Teknik Dan Vokasional (PTV) Di Malaysia. Persidangan Kebangsaan Penyelidikan dan Inovasi Dalam Pendidikan dan Latihan Teknik dan Vokasional CIE-TVT 2011, 16-17 November 2011, Pulau Pinang.

Aliff Nawi, Mohd Isa Hamzah dan Surina Akmal Abd Sattai (2014). Potensi Penggunaan Aplikasi Mudah Alih (Mobile Apps) Dalam Bidang Pendidikan Islam. O-JIE: Online Journal of Islamic Education, [S.1.], v. 2, n. 2, aug. 2017. ISSN 2289-3016. Retrieved from http://ojie.um.edu.my/index.php/O-JIE/article/view/5470 [14 Mei 2018]

Anuar, Roslaili dan Wan Zakaria, Wan Zamani (2015). TPACK dalam Pendidikan Seni Visual: Satu Kajian Mengenai Kesediaan Pelajar Menggunakan E-Pembelajaran dalam Pembelajaran Pendidikan Seni Visual. Jurnal Seni dan Pendidikan Seni ISSN 2289-4640 / Vol. 3 (2015) / (8-18).

Chad Udell, (2014). Mastering Mobile Learning. Retrieved from http://ebookcentral.proquest.com [16 May 2018]

Haizum Hanim Ab. Halim, \& Lai Chee Sern (2011). Penilaian Keberkesanan Kit Pengajaran Transistor Bagi Aliran Vokasional. Seminar Pasca Ijazah yang Pertama 201, pp 6-15. Retrieved from http://eprints.uthm.edu.my/3325/1/1.pdf [20 April 2018]

Ismail Basiron (2012). Kesan Kaedah Pengajaran Multimedia Interaktif Dalam Pengajaran Seni Visual. Retrieved From http://eprints.uthm.edu.my/4226/1/ISMAIL_BIN_BASIRON.pdf [3 April 2018]

Kementerian Pendidikan Tinggi (KPT) (2015). Dasar e-Pembelajaran Negara 2.0. Retrieved from http://smart2.ums.edu.my/pluginfile.php/2/course/section/2/Depan-20_2.pdf [1 April 2018]

Mohd Ismail Mustari Karjo, Kamarul Azmi Jasmi, Azhar Muhammad, Rujalah Abu Bakar \& Saodah Ahamad (2012).Permainan bahasa dalam pengajaran dan pembelajaran Bahasa Arab. In: Antarabangsa Perguruan dan Pendidikan Islam [SEAPPI2012] (International Seminar on Teacher and Islamic Education [SEAPPI2012]), 8-9 March 2012, Le Grandeur Palm Resort, Senai, Johor Bahru. Retrieved from https://www.researchgate.net/publication/293097816 [3 April 2018]

Whitton, N. (2010). Learning with digital games: A practical guide to engaging students in Higher Education. London: Routledge. ISBN 9780415997751. Retrieved from http://dmitrov.edu.ru/ ps/files/Learning_with_Digital_Games.0415997747_0415997755_0203872983.pdf [24 April 2018] 